\title{
GEOMORPHOLOGICAL UNITS AND LANDCOVER MAP OF WADI EL-NATRUN AREA USING REMOTE SENSING AND GIS TECHNIQUES, WESTERN DESERT, EGYPT
}

\author{
Ismail M. M., M.K. Abdel Gaffar and M.A. Azzam \\ Soils, Water \& Environment Research Institute, \\ ARC, Giza, Egypt
}

ABSTRACT

Wadi EL-Natrun area is one of the promising areas in the Western Desert for reclamation and utilization due to its location and the presence of ground water in a suitable quality for irrigation. It is located in the northeast corner of the Western Desert between longitudes $30^{\circ} 00^{\prime}$ and $30^{\circ} 30^{\prime}$ East and latitudes $30^{\circ} \quad 15^{\prime}$ and $30^{\circ} 30^{\prime}$ North. Wadi El-Natrun is a morphotectonic depression, having the lowest portion at its center $(-23 \mathrm{~m}$ ASL) with gradual increase elevation towards the outer margins of the depression. The geomorphological characteristics of Wadi El-Natrun depression and their surrounding lands were studied using the remote sensing (RS) and geographic information system (GIS) techniques. Landsat $\mathrm{ETM}^{+}$ image (2006), Triangulated Irregular Network (TIN map), Digital Elevation Model (DEM map), geological map and data verification by in situ observation were used for delineating the main geomorphologic units. The study area (acreage 135890 hectares) could be divided into four main regions; namely hills (foot slope and table land), Wadi terraces, Wadi depression (Aeolian deposits, alluvium deposits hectares and lakes \& sabkhas) and alluvial plain. Each of these regions showed distinct geomorphological features. Landcover classes were typically mapped from digital remotely sensed data through the process of supervised digital image classification. The study area was classified into five main classes with specific spectral signature for each class as follows: cultivated land (27040 hectares), bare soil and high land (98048 hectares), sand sheet (5164 hectares), urban (4838 hectares) and lakes \& sabkhas (938 hectares). Descriptions of these landcover classes are presented.

Key words: Wadi El-Natrun, geomorphological units, landcover map Remote sensing (RS) and geographic information system (GIS).

\section{INTRODUCTION}

Wadi EL-Natrun area is one of the promising areas in the Western Desert for reclamation and utilization due to its location and the presence of ground water in a suitable quality for irrigation. It is located in the northeast corner of the Western Desert between longitudes $30^{\circ} 00$ and $30^{\circ} 30$ East, and latitudes $30^{\circ} 15^{\prime}$ and $30^{\circ} 30^{\prime}$ North (Fig.1). Wadi El Natrun Depression (W.N.D) has an oval shaped, with about $50 \mathrm{~km}$ in length and its width ranges from 15 to 20 $\mathrm{km}$. The total area of the depression that lies below sea level $(0-23 \mathrm{~m} \mathrm{BSL})$ is about 50000 hectares. The origin of the underground water in Wadi El-Natrun is seepage from the Nile stream, due to its proximity and low level (ElMaghraby, 1990). Wadi El Natrun area is considered as an extremely arid region where the mean annual rainfall, evaporation and temperature are 41.4 $\mathrm{mm}, 114.3 \mathrm{~mm}$ and $21^{\circ} \mathrm{C}$ respectively (Egyptian Metrological Authority, 1996).

Fayoum J. Agric. Res. \& Dev., Vol.23, No.2, July, 2009 
This study aims at using Remote sensing (RS) and Geographic Information System (GIS) to identify the geomorphological units and landcover / landuse map of Wadi EL-Natrun area, Western Desert, Egypt.

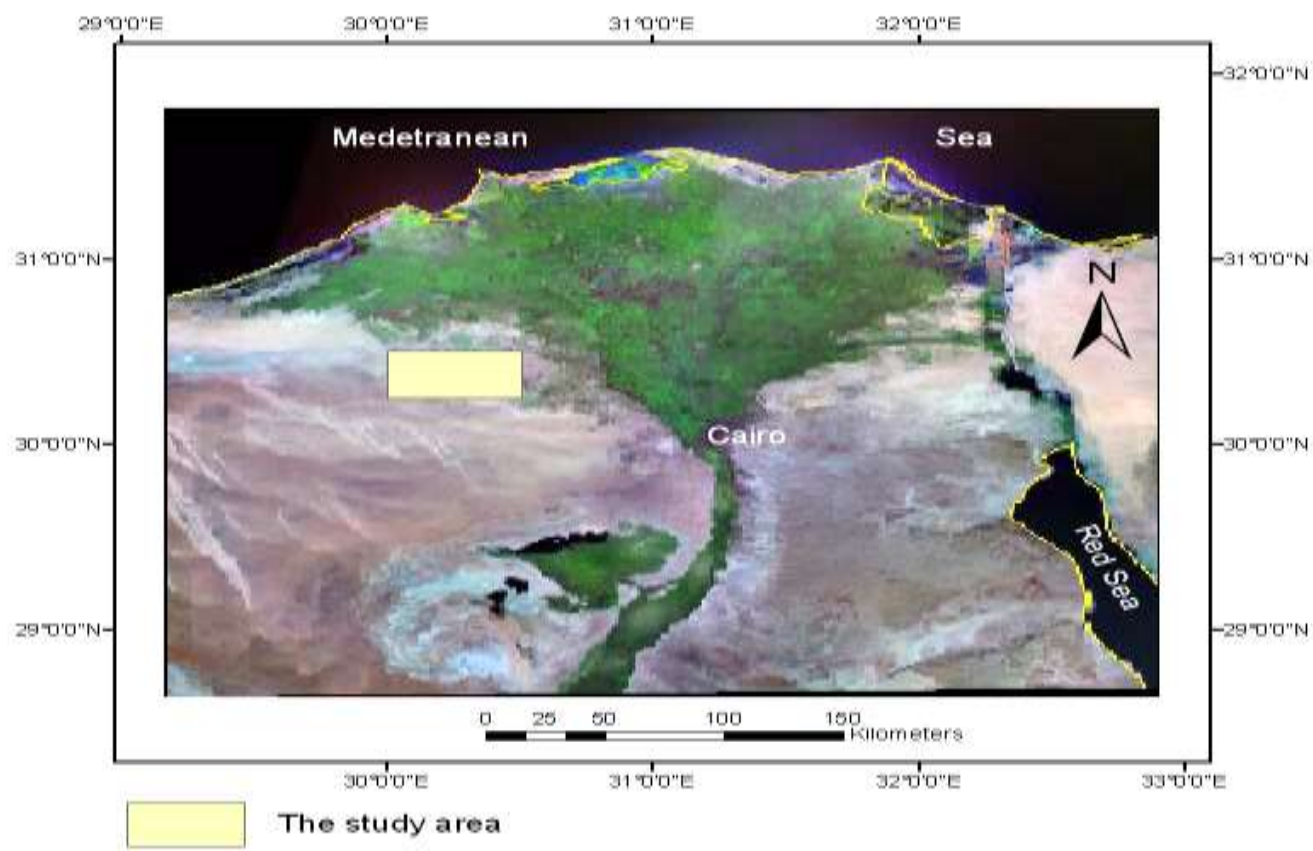

Fig. (1): Location map of the study area

\section{Geology of Wadi EL-Natrun:}

Geology of Wadi El-Natrun was studied by many authors e.g. Beadnell (1931), Said (1962, 1990) and Hendriks et al., (1984).

In Wadi EL-Natrun depression, the surface is underlain by both Tertiary and Quaternary sediments with local outcrops of basalt and diorite (Fig.2). These rocks display different litho faces (sand, gravel condition). The surface sandstone and clay limestone...etc belonging to different geological environments are rather simple while the subsurface structures are very complicated.

\section{A- Tertiary strata:}

In the study area, the Tertiary section was distinct into the following stratigraphic units: Pliocene and Miocene. The Pliocene and Miocene portion have mostly a direct contribution on Wadi EL-Natrun loose sediments (soils). The following is a brief description of the surface sediments and rock exposures existing in the study area.

\section{1-Pliocene:}

In Wadi EL-Natrun area, the Pliocene is dominated by shallow marine and brackish water deposits which overlain by Nilotic sands and gravel (Pleistocene) and underlain by a thick sandy section belonging to unconformable to lower Miocene (Moghar Formation). 
Upper and Middle Pliocene: (Wadi EL-Natrun Formation):

These sediments are largely restricted to the depression area and are essentially developed into gypseous clays and sands of typical brackish water origin. The portion of Pliocene was distinct into two series, i.e., an upper (El Mulok) and a lower series (Beni Salama).

El Mulok series:

This series outcrops within Wadi EL-Natrun depression; it was developed into gypseous clays and sands with thin intercalation of marls and having a thickness of about 30m. According to EI Sheikh (2000), this series forms most of the rocky hills protruding from the depression floor i.e Qaret El Mulok located at the central portion of the depression south El Hamra Lake. The exposed section of this series is dominated by dark grey clay of about $15 \mathrm{~m}$ thickness, while the subsurface section, as determined from several water wells drilled in the depression, is composed of pyritic dark grey clay alternating with sand beds of about $140 \mathrm{~m}$ thickness.

This series has been recorded in the east of Wadi EL-Natrun area underlying a thick cover of Pleistocene deltaic deposits. It can be justified to assume a brackish water environment of deposition either in form of a near shore lagoon or lacustrine at north-and north Western parts.

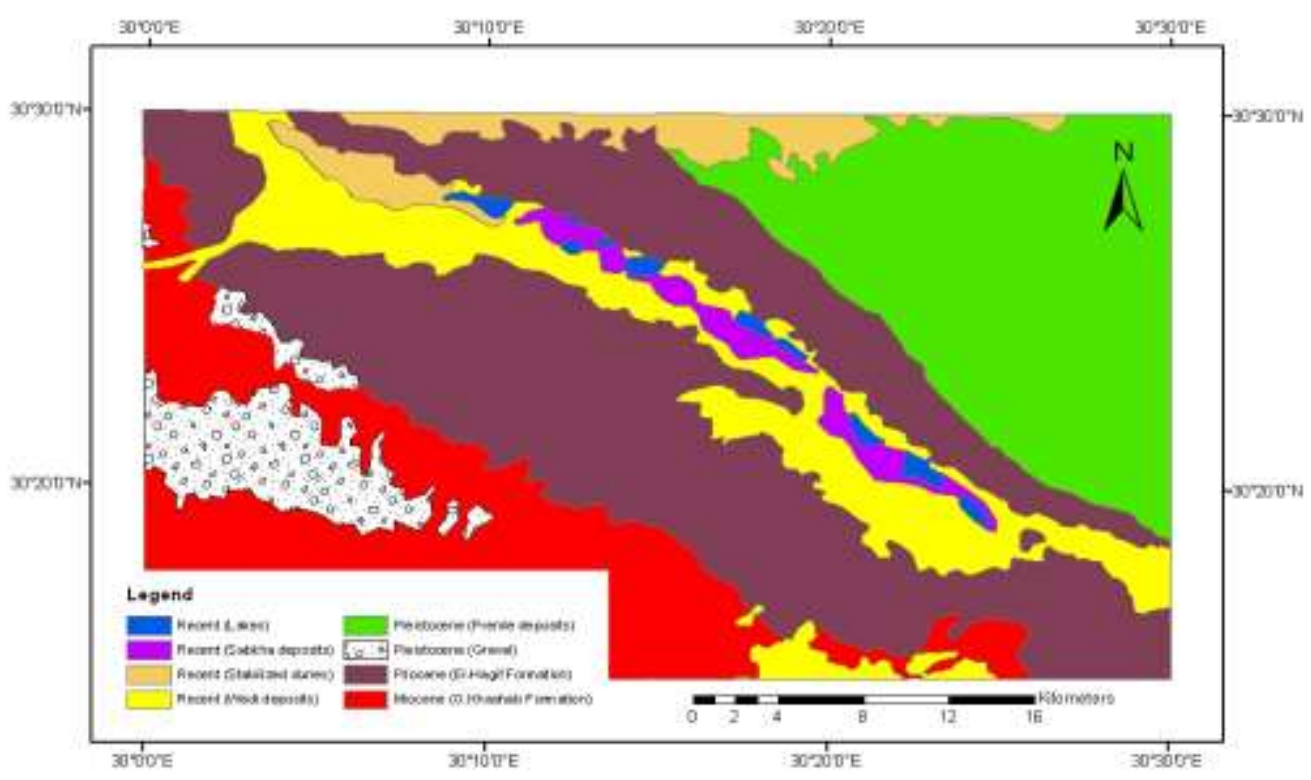

Fig. (2):Geological map of Wadi El-Natrun area (Modified after CONCO,1987).

\section{Beni Salama series:}

This series is dominated by interbeded argillaceous sands and flinty limestone (30m), upper portion. The lower part of Beni Salama series (10m) is dominated by unfossiliferous sands. This series are widely distributed in the surface at several places in Wadi EL-Natrun, particularly at Beni Salama

Fayoum J. Agric. Res. \& Dev., Vol.23, No.2, July, 2009 
depression. In the subsurface, Beni Salama series is observed in nearly all wells drilled for water within Wadi EL-Natrun depression and has nearly the same lithological characteristics as exposure.

\section{Lower Pliocene (El Mekhimin Formation):}

In Wadi El-Natrun rocks assigned tentatively to the lower Pliocene are exposed in the southern portion of the depression area, namely El Mekhimin, Gabal El Hdid....etc. In all such localities the exposures are dominated by calcareous conglomerate and sandstone having a thickness of about $5 \mathrm{~m}$, this overlies poorly fossiliferous sandstone.

\section{2- Miocene (thickness $200 \mathrm{~m}$ ):}

Within the area occupied by Wadi EL-Natrun depression, exposures of Miocene rocks are not known but outside the depression area to the south, Miocene rocks have a wide distribution and are developed essentially into sand faces. One of the type localities, where Miocene rocks are exposed is Quaret El Raml (located some 50km to the south-east of Wadi EL-Natrun). In this locality, the exposed Miocene section has a thickness of about $50 \mathrm{~m}$. Miocene sediments are well known in most deep wells drilled for water in Wadi EL-Natrun and Wadi El Farigh south Wadi El-Naturn (Moghra formation).

\section{B-Quaternary:}

In Wadi EL-Natrun area, Quaternary strata can be categorized into two main types of deposits belonging to the Recent and Pleistocene, varying in thickens from $1 \mathrm{~m}$ to $80 \mathrm{~m}$ and can be differentiated into the following deposits:

a) The Nilotic sands and gravel is the lowest part of the Quaternary section and have variable thickness less than $10 \mathrm{~m}$ in the depression area and more than $300 \mathrm{~m}$ in Delta Basin. The other parts some of them are thin in the depression (Lacustrine deposits), while the others are found both in and outside it. These Nilotic sands and gravel are built of loose quartz sands and gravel with thin streaks of gray sandy clay. Sandford and Arkell (1939) and Ball (1939) show that these sands and gravel were originally brought into the Nile Basin from the surrounding high lands through a number of its lateral derivatives.

b) The pink limestone overlying the Nilotic gravel and sands has been described as a (crustal Formation). Blankenhorn (1921) regarded it to the early Quaternary, while Sandford and Arkell (1939) assigned it to a Miocene age. Boyed (1947) recognized four phases of the pink limestone two associated with (Mulok Formation). El-Fayoumy (1964) and Shata (1955) conclude that it is a crust formation. The deposition of this crust bears a relationship to the changes of the climate from the west condition to the extreme aridity. According to Sallouma (1964) and El Sheikh (2000), the surface exposures are consisted of gravel and loose sands.

The Quaternary sediments include the Pleistocene Prenile sediment, Aeolian sand accumulation and stabilized dunes, the lacustrine deposits (the

Fayoum J. Agric. Res. \& Dev., Vol.23, No.2, July, 2009 
salt lakes and sabkhas) and the gravelly deposits of the Nile and calcareous crust.

\section{MATERIALS AND METHODS}

1-Source of data:

The data used include satellite image, topographic map and geological map.

- Topographic map with 1:50,000 scales produced by the Survey Authority of Egypt (1994), based on aerial photographs in 1993 and modified by field survey in 1993.

- Geological map with 1:50.000 scale (CONCO, 1987).

- Satellite data $\left(\mathrm{ETM}^{+}\right.$with path and row 177 and 39 respectively, acquired in 2006).

\section{2-Field investigations:}

Geomorphological and geological field investigations were carried out in the study area using geological map, topographic map and landsat $\mathrm{ETM}^{+}$ image.

3-Geographic Information System (GIS) application:

- The topographic data conversion to digital form by scanning,

- The used spatial data were geometrically corrected to ETM, Red belt,

- On screen digitizing and features analysis was achieved by the aid of Arc GIS 9.2 package,

- Triangulated Irregular Network (TIN) and digital elevation model (DEM) models of the study area were built up by contour lines and spot heights extraction from the topographic map (1:50000) and the analysis in Arc GIS 9.2 ,

- The main geomorphological units of the region were identified aided by DEM visual interpretation and guided by both of TIN and Landsat ETM ${ }^{+}$ image as well as geological map and supplemented by in situ data acquisition. The "physiographic analysis" detailed by Zinck and Valenzuala (1990) were used to nominate the mapping units,

\section{4-Remote sensing technique:}

The following section gives a brief background about the Remote sensing techniques and illustrates the main steps undertaken starting with preprocessing, followed by processing techniques to produce the final output digital image data, using ERDAS IMAGEN 9.1 programming.

\section{A-Image Preprocessing:}

- Geometric correction: This process includes calculation of a satellite model, matching ground and image-based control points, transformation and resampling the data to a map projection co-ordinate system (Hteillet $\boldsymbol{e t}$. $\boldsymbol{a l}$., 2000). In this study the rectification process was carried out using topographic maps (1994) and ground control point GPS procedure. The root mean squares error for the rectified image 2006 was 0.21 pixels. The image thus was rectified and registered according to the Egypt Transverse Mercator (ETM) projection using the cubic convolution technique.

-Image enhancement and visual interpretation: The goal of image enhancement is to improve the visual interpretability of an image by increasing the apparent distinction between the features. The process of visually interpreting digitally enhanced imagery attempts to optimize the complementary abilities of the human mind and the computer. The mind is excellent at interpreting spatial attributes on an image and is capable of identifying obscure or subtle features (Lillesand and Kiefer, 1996).

Fayoum J. Agric. Res. \& Dev., Vol.23, No.2, July, 2009 
B-Supervised classification is an information-extraction process that analyzes the spectral signatures and then assigns pixels to categories based on similar signatures. A classification procedure has been applied to extract natural resources land cover/land use classes. The first step in the supervised classification is to select training sites for each of the study area. To achieve this objective, land covers are represented by more than five training sites in order to cover the full range of reflectance characteristics. These sites were selected to build up the spectral signature library for the image. Supervised classifications were generated as a more precise means of determining the spatial extent of land-use/land-cover. This technique provides a means to identify and distinguish regions based on spectral differences (Jensen, 1996 and Lillesand and Keifer, 1996).

\section{RESULTS AND DISCUSSION \\ Geomorphological Units:}

The geomorphological characteristics of Wadi el-Natrun depression and their surrounding lands were studied using the remote sensing (RS) and geographic information system (GIS) techniques. Wadi El-Natrun is a morphotectonic depression, having the lowest portion at its center (-23m ASL) with gradual increase elevation towards the margins of the depression as shown in the distribution of contour lines and spot high.

Landsat $\mathrm{ETM}^{+}$image (Fig.3), Triangulated Irregular Network (TIN map, Fig.4), digital elevation model (DEM map, Fig.5), geological map and data verification by in situ observation were used for delineating the main geomorphologic units. The study area (135890 hectares) can be divided into four main regions; namely hills, Wadi terraces, Wadi depression and alluvial plain regions (Fig.6). Each of these regions shows distinct geomorphological features:

\section{1-Hills region:}

This region includes two units; namely, the table land and the foot slope. Brief descriptions of these units is here lighting after:-

\section{A-Table Land unit:}

This unit occupies the southern part of the study area (acreage 38488 hectares) and formed of few scarps of low topographic relief (from about 55 to $182 \mathrm{~m}$ ASL in elevation), they occur in the form of elongated ridges bordering the two main depressions of Wadi El-Natrun and Wadi El Farigh. Some places are capped by hard feruginated sandstone as in Gabal El Hadid or conglomerate limestone as in Gabal El Mikheimin. Others are capped by conglomerate sandstone and chert gravel as in Beni Salama and Kafr Dawod. Barakat and Abu Khadrah (1973) mentioned that the main topographic scarps in the present area are Gable El Hadid, Gabal El Mikheimin, Gabal Abou Melah and Gabal El Qantara.

\section{B- Foot Slope unit:}

This geomorphologic unit lies around the Table land unit (acreage 15495 hectares). It is mainly composed of thick sedimentary section belonging mainly to Pliocene and Miocene sequences. This subunit ranges from about 30 to $55 \mathrm{~m}$ ASL in elevation with moderate slope toward El-Natrun depression.

The Foot slope unit (Fig.6) characterized by its dense consequent net of drainage lines running for short distances down-dip slope. Major subsequent drainage lines running in SW-NE trends, follow the contact between the Table land unit and the Natrun depression. The drainage lines are more or less

Fayoum J. Agric. Res. \& Dev., Vol.23, No.2, July, 2009 
parallel to the dipping of the rock strata and following the slope towards the NE direction.

\section{2-Wadi Terraces:}

This unit is distributed around the depression floor of wadi El-Natroun and its elevation ranges from 0 to $30 \mathrm{~m}$ ASL with moderate slope toward the depression floor (acreage 16638 hectares). The wadi terraces of the study area can be divided into the northern and southern terraces.

The northern terrace cover the portion located between the alluvial plain and wadi El-Natrun depression floor. This is terminated at its upper portion by a remarkable edge which is really morphological echo of both folding and faulting (Shata et al., 1984). The northern terrace is distinguished into a number of steps or benches which correspond to the equivalent lithological variation. The surface of this slope is either degraded or covered with downwash deposits. The slope surface is dissected by a number of short shallow runnels; all directed towards the central depression areas.

The southern terrace is rolling surface sloping in the northward direction from El-Mikhimien edge to Wadi El-Natrun depression. This slope is underlain by sands and sandstone belonging to Early Pliocene and is almost covered by a thin gravel mantle. This terrace is dissected by a number of oriented Wadis which are all directed to the low land areas towards the depression floor of Wadi El-Natrun.

\section{3-Wadi depression region:}

This region occupies both of wadi El-Natrun and wadi Al-Farigh depressions. These two depressions resulted from morphotectonic activities. The ground elevations of these two depressions range from -23 to $30 \mathrm{~m}$ ASL. The structural depression of Wadi El-Natrun represents a large eroded doubly-plunging anticline structure oriented in a NW-SE direction and bounded by normal faults. The length of Wadi El-Natrun depression is about $60 \mathrm{~km}$ and its maximum width is about $15 \mathrm{~km}$. The Wadi El-Natrun landscape is affected by human activities, mainly in relation to agriculture and tourism.

According to the topographic conditions (relief and slope), tectonic setting (fractures, faults and folds), lithology of source area and soils; wadi El-Natrun depression can be subdivided into the following three geomorphologic units (Fig.6):

A- Aeolian deposits: These deposits were formed by wind action that manifested in the creation of some local cut and fill depression (acreage 2281 hectares). These Aeolian accumulations consist essentially of well sorted loose, fine to medium quartz size. The wind action is considered as one of the most effective factors that modify the land of the study area. The erosional and deposional process of wind action is considered as one of the most active and effective exogentic processes that lead to the scouring of Wadi El-Natrun depression.

B- Alluvium Deposits: These deposits were formed by water action of the wadis running from the adjacent high lands (Gabal El-hadid) to the depression of wadi El-Natrun during flooding (acreage 28814 hectares). The erosional and depositional processes of water action lead to the accumulation of variable grain size deposits. The thickness of these deposits is larger corresponding to the Aeolian deposits. This unit occupies the largest area in wadi El-Natrun depression.

C- Salt Lakes and sabkhas: Wadi El- Natrun depression is occupied by a series of salt-water lakes, which are the lowest elevation in the depression and

Fayoum J. Agric. Res. \& Dev., Vol.23, No.2, July, 2009 
is usually occupied by saline water (acreage 885 hectares; Fig.6). These perennial lakes stretch for a distance of about $30 \mathrm{~km}$ in the northwestern direction. Most important of them are from northwest to southeast; El-Gaar, Khadra, El-Beida, El-Saad, El-Hamra, Gabboura, El-Rasoneya. The saline lakes receive saline water from the underlying groundwater through the faults and joints. The level of water in these lakes is fluctuated seasonally, becoming higher in the autumn and the winter and lower in the spring and the summer. This is much related to the general fluctuation of the groundwater table and the variation of the evaporation rate. The saline waters in these lakes are rich in Natrun and halite salts. The salt marches occupy the area between and around the salt lakes. The surface of these marches is covered with sabkha consisting of crystalline gypsum, sand and clay with some calcareous materials.

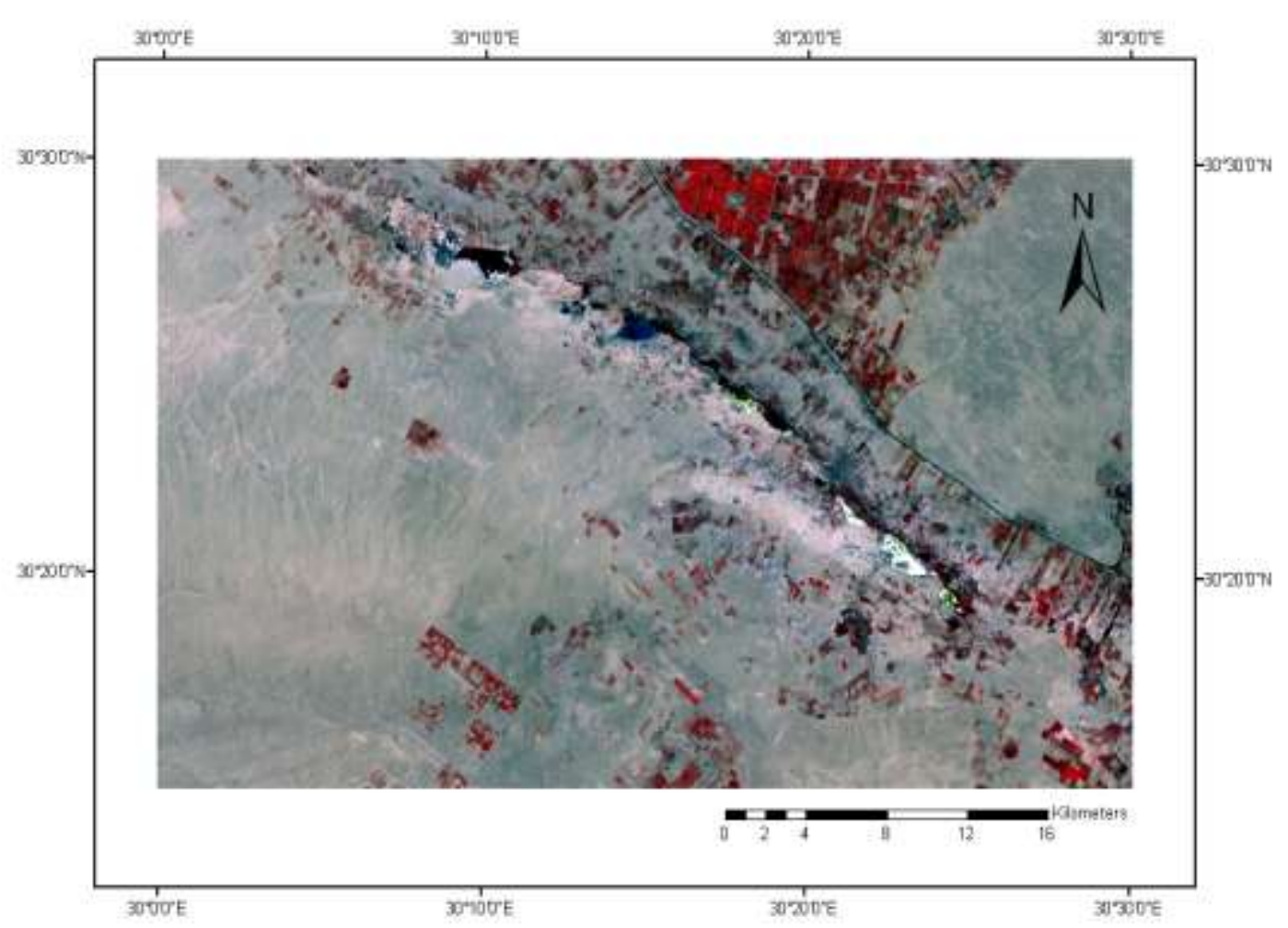

Fig. (3): False color image of subset Landsat $\operatorname{ETM}^{+}$(2006) bands 3,2,1.

\section{4-Alluvial Plain:}

The alluvial plain unit occupies the area stretched between Wadi El Natrun depression on the southwestern side and Rosetta branch on the northeastern side and it is underlain by dark brown gravel and coarse sand (acreage 33289 hectares). The surface of this plain is gently undulating and is dissected by shallow runnels directed either to the Nile Delta or to Wadi El Natrun depression. The elevation of the ground ranges between $25 \mathrm{~m}$ ASL in the southwestern part and $50 \mathrm{~m}$ ASL adjacent to the Delta in the eastern part. This plain is locally overlain by stabilized and active dunes and displays many

Fayoum J. Agric. Res. \& Dev., Vol.23, No.2, July, 2009 
features of deflation. Also, there is several shallow drainage patterns drain this plain, where the majority of their drainage lines are mainly directed towards the Rosetta branch.

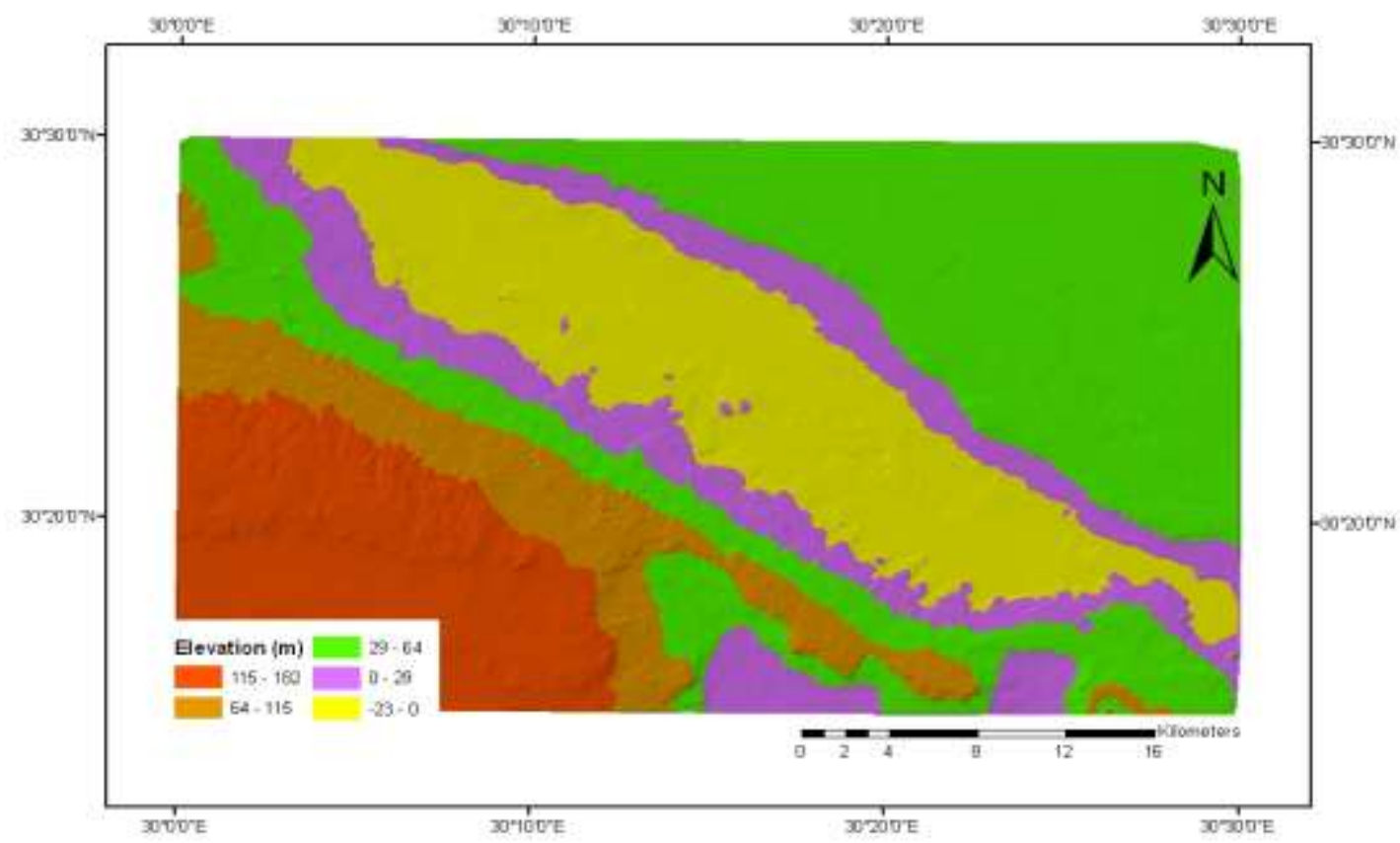

Fig. (4): TIN output map of the study area.

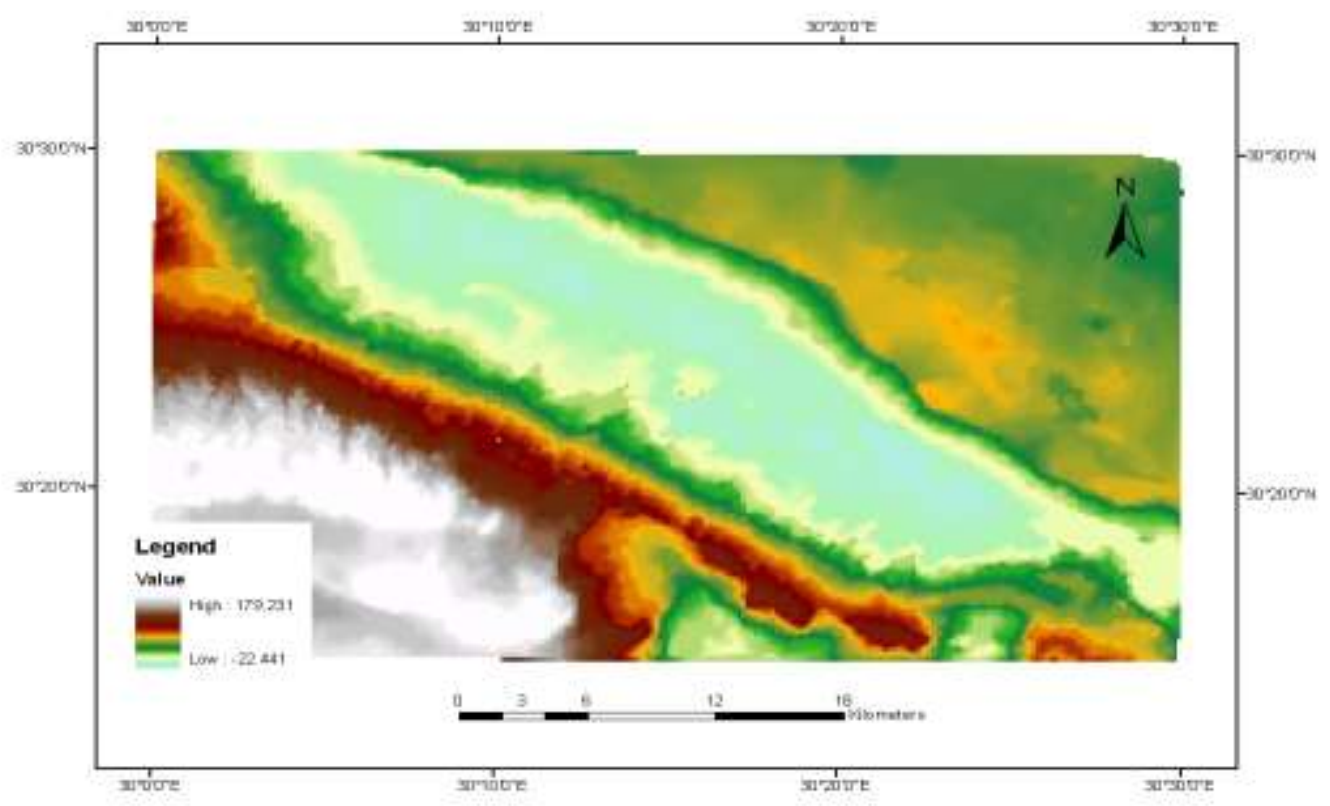

Fig. (5) DEM output map of the study area.

Fayoum J. Agric. Res. \& Dev., Vol.23, No.2, July, 2009 


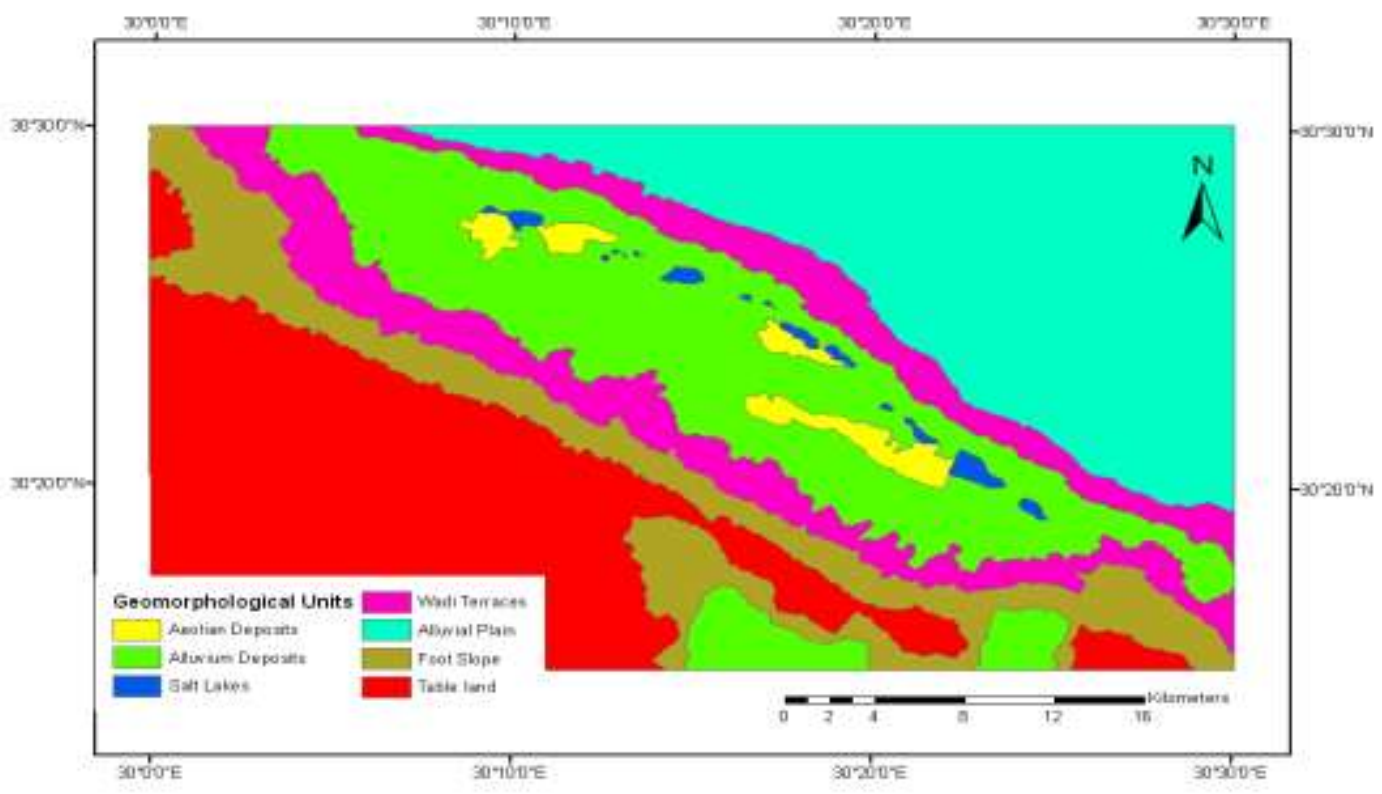

Fig (6): Geomorphological units of the study area.

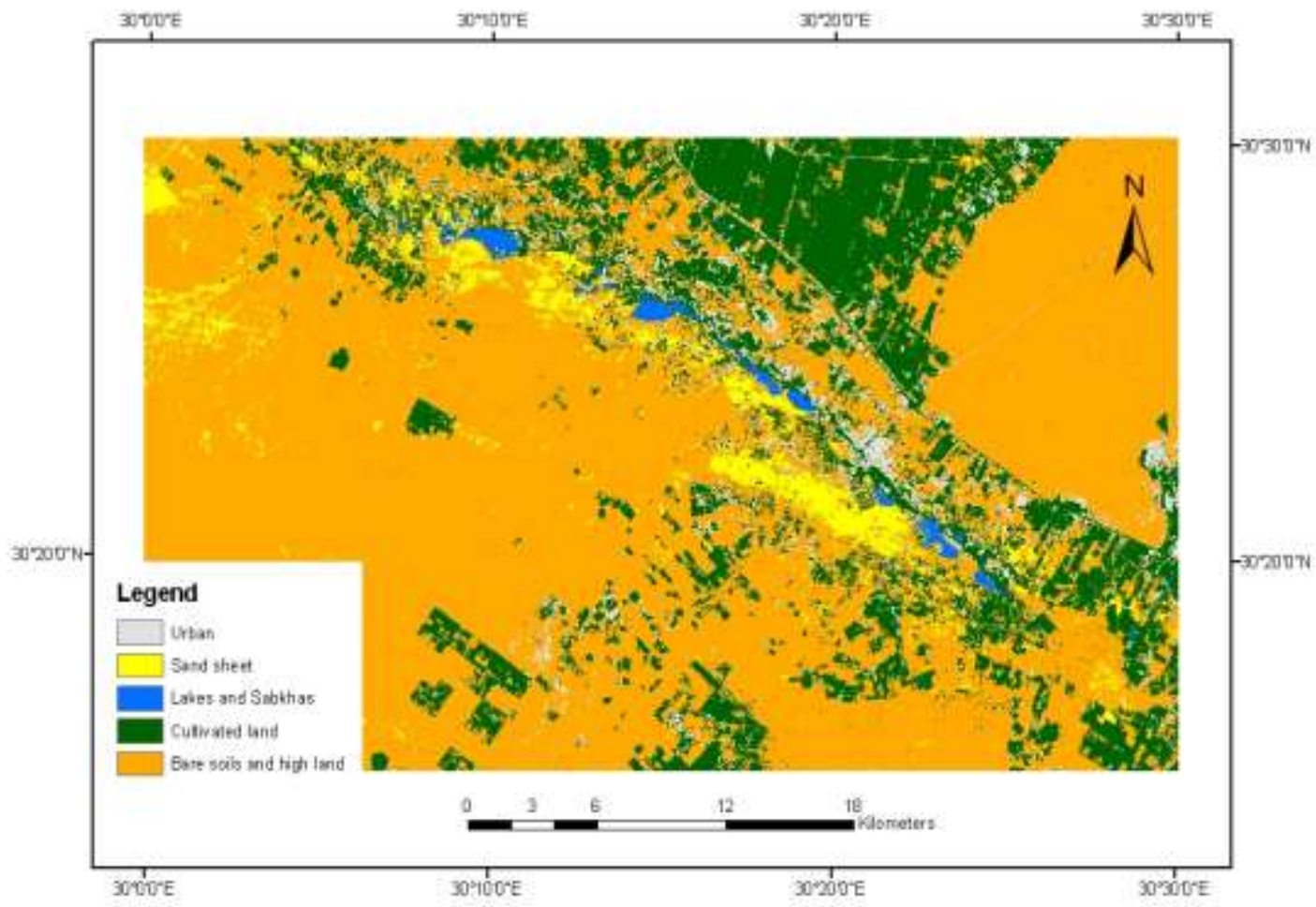

Fig. (7): Landcover/landuse map of the study area from landsat $\mathrm{ETM}^{+}$image (2006).

Fayoum J. Agric. Res. \& Dev., Vol.23, No.2, July, 2009 


\section{Land use/Land cover of the study area:}

Land cover classes are typically mapped from digital remotely sensed data through the process of supervised digital image classification (Campbell, 1996). The overall objective of the image classification procedure is to automatically categorize all pixels in an image into land cover classes or themes (Lillesand and Kiefer, 1996). The maximum likelihood classifier quantitatively evaluates both the variance and covariance of the category spectral response patterns when classifying an unknown pixel, so that it is considered to be one of the most accurate classifier since it is based on statistical parameters.

There are two steps to classify the land cover of the study area as follows:

1- Field investigations and other available data (e.g. digital topographic map) to determine the different signature points of the study area. These spectral signatures are used as training areas for maximum likelihood supervised classification

2- Supervised classification: The final output signatures of the first step are used as training areas for supervised classification. The study area was classified into five main classes with specific spectral signature for each class as follows: cultivated land, bare soil and land, sand sheet, urban and lakes \& sabkhas (Fig.7). Description and area of these land cover classes are presented in the following Table:

\begin{tabular}{|c|l|c|c|}
\hline Class & \multicolumn{1}{|c|}{ Description } & $\begin{array}{c}\text { Area } \\
\text { (hectare) }\end{array}$ & $\begin{array}{c}\text { Percent- } \\
\text { age }\end{array}$ \\
\hline $\begin{array}{c}\text { Cultivated } \\
\text { land }\end{array}$ & $\begin{array}{l}\text { Cultivated land is mostly located in the northwest } \\
\text { part of alluvial plain unit and also scattered in the rest } \\
\text { units as sparse vegetation. Areas cultivated with } \\
\text { annual crops, vegetables, or fruits. These crops are } \\
\text { irrigated mainly from the under ground water. Most } \\
\text { of the cultivated area is newly reclaimed. }\end{array}$ & 27040 & 19.9 \\
\hline $\begin{array}{c}\text { Bare soils } \\
\text { and high } \\
\text { land }\end{array}$ & $\begin{array}{l}\text { Bare soils are located in the southeast part of alluvial } \\
\text { plain and Wadi alluvial units It is covered by sparse } \\
\text { natural vegetation and are promising for reclamation. } \\
\text { High land are located mainly in the southern part of } \\
\text { the study area and represented by the mountainous } \\
\text { region. }\end{array}$ & 98048 & 72.1 \\
\hline $\begin{array}{c}\text { Sand sheet } \\
\text { Sand sheet is mainly represented by Aeolian deposits } \\
\text { unit and composed of loose sand with surface saline } \\
\text { layer and less suitable for reclamation. }\end{array}$ & 5164 & 3.8 \\
\hline Urban & $\begin{array}{l}\text { Includes city buildings (Sadat city) and some villages } \\
\text { as well as sporadic farmers' houses and some } \\
\text { Christian buildings. }\end{array}$ & 4838 & 3.5 \\
\hline $\begin{array}{c}\text { Lakes and } \\
\text { Sabkhas }\end{array}$ & $\begin{array}{l}\text { Series of salt-water lakes, which are the lowest } \\
\text { elevation in the depression and it is usually occupied } \\
\text { by saline water. Sabkhas are located between and } \\
\text { around the lakes. The surface of these areas is } \\
\text { covered with sabkha consisting of crystalline } \\
\text { gypsum, sand and clay with some calcareous } \\
\text { materials }\end{array}$ & 938 & 0.7 \\
\hline
\end{tabular}

Fayoum J. Agric. Res. \& Dev., Vol.23, No.2, July, 2009 


\section{REFERENCES}

Ball, J. (1939): Contribution to the Geography of Egypt. Survey and Mine Dept., Cairo, Egypt.

Beadnell, H.J.L. (1931): "Zerzura", Geograph.J. 77:245-250.

Blanckenhorn, M. (1921): Handdbuch der regionalen geologie Agypten, Heidelberg, Bd 1, VII,Abt. 9 , Heft .

Boyed, W.R. (1947): A preliminary note on a geological reconnaissance survey of the Quattara area, Western Desert, Egypt. Unpublished report, General Petroleum Company, Cairo.

Campbell, J.B. (1996): Introduction to remote sensing; second edition, The Guilford Press, New York; 156p

CONOCO (1987): Geological map of Egypt 1:50000.NH 36 NW CAIRO, Egypt.

Egyptian Metrological Authority (1996): Climatic Atlas of Egypt .Public Arab Republic of Egypt, Ministry of Transport, Cairo, Egypt.

El-Fayoumy, I.F. (1964): Geology of groundwater supplies in Wadi ElNatrun area .M.Sc. Thesis, Fac. Sci., Cairo Univ., 109 p .

El- Maghraby, M.M. (1990): Geographical and hydorological studies of Sadat City, Egypt. M.Sc.Thesis, Fac. Sci., Alexandria University.

El-Sheikh, A.F. (2000): Hydrology of the area North and West of Wadi ElNatrun. M. Sc. Thesis, Fac.of Sci. Minufiya Univ., Egypt.

Hendricks, F.; Luger, P.; Kalleribach, H.and Schroerer, J.H. (1984): Stratigraphical and sedimentological framework of the Kharga-Sinn el Kaddab Stretch (Western and Southern part of the upper Nile Basin), Western Desert, Egypt, Berliner Geowise. Abh., (A), 50: 117-151, Berlin.

Hteillet, P.M., El Saleous N., Hansen M.C., Justice C.O. and Townshnd J.R.G. (2000): An evaluation of the global 1-Km AVHRR land dataset; Int. Remote Sensing; 21: 1987-2.

Jensen, J.R. (1996): Introductory Digital Image Processing Prentice-Hall, Upper Saddle River, NJ 316 pp.

Lillesand, T.M. and Kiefer, R.W. (1996): Remote Sensing and Image Interpretation, John Wily and Sons, New York.

Said, R. (1962): The geology of Egypt. Elsevier Publ., Amsterdam- New York, 377p.

Said, R. (1990): The geology of Egypt. Published for the Egyptian Central Petroleum Corporation (CONCO), Hurghada Inc. by Balkema, A.A., Roterdam; the Netherlands.

Sallouma, M.K. (1964): Geology and geomorphology of Beni Salama area of Wadi El-Natrun. M.Sc. Thesis, Fac. of Sci., Ain Shams Univ., Egypt.

Sandford, K.S. and Arkell, W.G. (1939): Paleolithic Man and the Nile Valley in lower Egypt. Chicago Univ, Oriental Institute Publications.

Shata, A.A. (1955): An introduction note on the geology of the northern portion of the Western Desert of Egypt. Bull .Inst. Desert, Egypt, Vol. No.3.

Shata, A.A., El-Fayoumy, I.F. and Sallouma, M.K. (1984): Geomorphology of Bani Salama area (the region west of the Nile Delta). Bull. Fac. Sci. Mansoura Univ.,pp.30-31.

Survey Authority of Egypt (1994): Topographic maps of Wadi El-Natrun area with 1:50,000 scales.

Fayoum J. Agric. Res. \& Dev., Vol.23, No.2, July, 2009 
Zinc, J.A. and Valenzuela (1990): "Soil Geographic Database", Vol.3, ITC, Ensched, Netherlands.

الوحدات الجيومورفولوجية وخريطة الغطاء الأرضى لمنطقة وادى النطرون باستخدام تقنيات

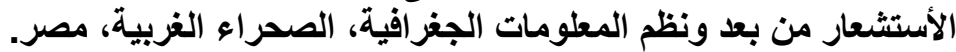

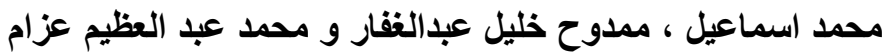

معهل بحوث الأراضى والمياه والبيئه- مركز البحوث الزيل الزراعيه

تعتبر منطقة و ادى النطرون من المناطق الو اعدة فى الصحر اء الغربية بالنسبة للزر اعـة و اقامـة

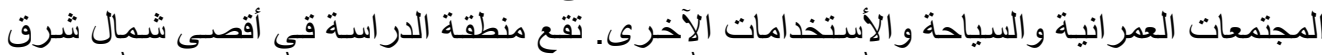

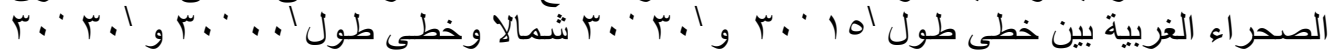

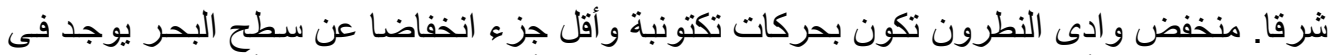

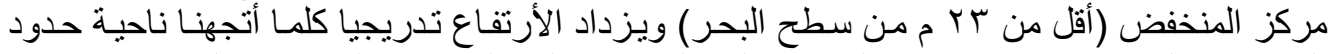

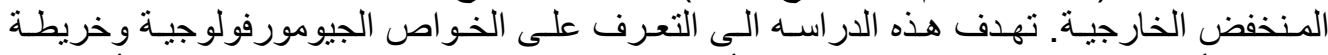

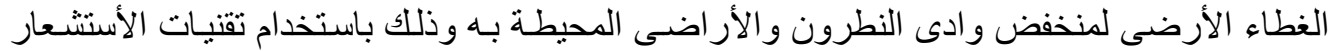

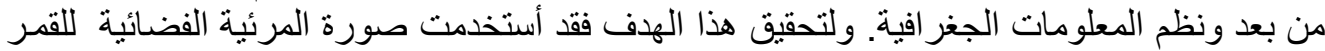

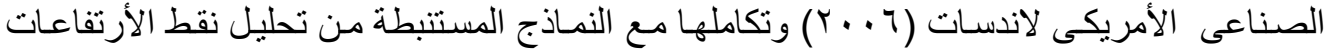

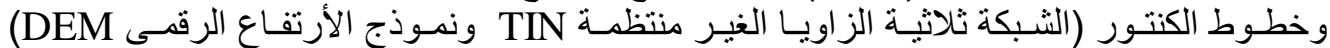

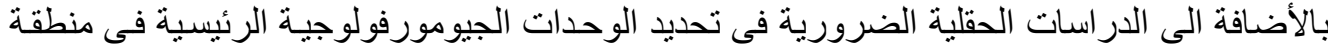

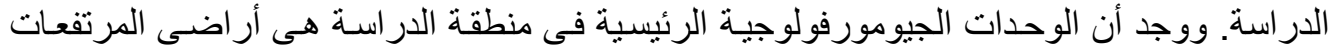

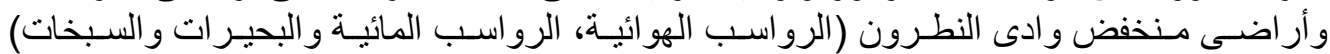

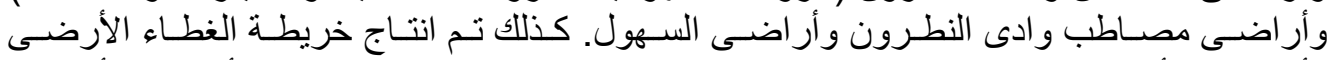

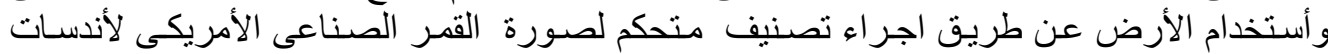
وهن و Supervised classification

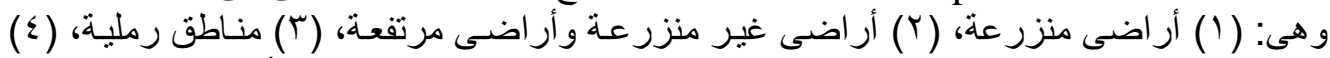

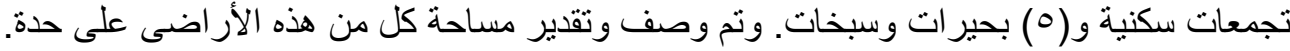

